\title{
International Journal of Business and Management
}

www.ccsenet.org/ijbm

January 2010

\section{FDI in BRICs: A Sector Level Analysis}

\author{
Yunyun Duan \\ School of International Business, Southwestern University of Finance and Economics \\ Chengdu 611130, China \\ E-mail: 1xin111107@sina.com
}

\begin{abstract}
This paper attempts to compare the overall trends and industrial patterns of inward foreign direct investment in the BRICs and explain their determinants. The overall trend of the inward FDI in the BRICs is increasing. Nevertheless, the industrial patterns of inward FDI are different from each other. In addition, there are three main factors that determinant the industrial patterns of inward foreign direct investment in the BRICs: develop courses, resources and the business environment.
\end{abstract}

Keywords: Inward FDI, BRICs, Industrial pattern

\section{Introduction}

"The combined economies of Brazil, Russia, India and China (BRICs) appear likely to become the largest global economic group by the middle of this century." (Cheng, Gutierrez, Mahajan, Shachmurove, and Shahrokhi, 2007). With this trend, the BRICs have attracted more and more FDI inflow and developed rapidly, which is out of imagination. FDI flows to Brazil declined from $\$ 22.5$ billion in 2001 to $\$ 16.6$ billion in 2002, a decline of more than 26\%. Despite this Brazil remained the largest recipient of FDI in Latin America. FDI flows remained relatively strong despite the crisis in Argentina, and the uncertain outcome of the presidential election in 2002 (World Investment Directory online). Following substantial increases during 1995-1997, FDI flows to the Russian Federation is at about US\$2.8 billion on average during the following four years. Compared the size of the Russian economy with the volume of flows to other countries in Central and Eastern Europe, the level of FDI in Russia is relatively low, suggesting that FDI in the country is still at an early stage (World Investment Directory online). Inward FDI stock in India in 2002 nearly doubled over the past four years. Inward FDI stock in India soared from less than US\$ 2 billion in 1991, when the country undertook major reforms to open up the economy to world markets, to about US\$ 45 billion in 2005 (UNCTAD, online database). Since 1980, China has grown at an average rate of around 10\% per year and China became the world's fourth largest exporter in 2002. The flow of FDI in 1993 reached a remarkable 26 billion US dollars (China State Statistics Bureau, 1994). "Many other developing countries have expressed the concern that the FDI into China represents a diversion of global direct investment away from them" (Wei, 1995). Due to the BRICs have attracted much of the world's FDI and become more important in the global market, it is reasonable to know the overall trends and industrial patterns of inward foreign direct investment in the BRICs.

This paper attempts to compare the overall trends and industrial patterns of inward foreign direct investment in the BRICs and explain their determinants.

The paper is organized in the following way. In Section 2, I provide a literature review of foreign direct investment in the BRICs. In Section 3, I attempt to compare the overall trends and industrial patterns of inward foreign direct investment in the BRICs. In Section 4, I try to explain their determinants and make the conclusion in Section 5.

\section{Literature Review}

With the rapid development of the BRICs, many scholars have done researches on them and try to find out their determinants.

Cheng, Gutierrez, Mahajan, Shachmurove, and Shahrokhi (2007) consider that while the BRICs are not sure to become economic hegemony in the world economy, the interplay between BRICs economies and other developing countries is viewed as a critical aspect of globalization and interdependence. Mcdonaldm, Robinson, and Thierfelder (2008) use a global general equilibrium trade model to analyze the impact of the dramatic expansion of trade by India, China, and an integrated East and Southeast Asia trade bloc and productivity growth in the region on developing countries. China is an integral member of the E\&SE Asia bloc, with strong links through value chains and trade in intermediate inputs, while India is not a part of any trade bloc. Chakraborty and Nunnenkamp (2008) assess the proposition that FDI in India will promote economic growth by subjecting industry-specific FDI and output data to Granger causality tests within a panel cointegration framework. It turns out that the growth effects of FDI vary widely across sectors. Felipe, Lavin and Fan 
(2008) document the diverging patterns of capital accumulation, profit rates, investment rates, capital productivity, and technological progress of China and India between 1980 and 2003. And find out the two Asian economies have followed very different growth patterns and now face different challenges. Lo and Liu (2009) extend other scholar' model to demonstrate why China has been so successful in disproportionately attracting foreign offshore manufacturing activities, while India has been engaged mainly in offshore service activities. They argue that the host country's industry-specific technology capabilities make the difference in FDI composition between China and India. They also find that, after excluding overseas Chinese investment, India is almost on par with China in terms of the market size it offers to marketing-seeking FDI. Fabry and Zeghni (2002) develop their understanding of FDI in Russia by asking a main question: Why is Russia an exception in the context of FDI globalization? Is Russia willing to stay outside the general trend of fierce competition for FDI and able to developed endogenously sustainable growth? Giner J and Giner G (2004) elaborate an interpretative model of foreign direct investment in China based on an integrated view of economic policy. The principal conclusions are both macroeconomic determinants and sociopolitical factors that bear upon the flow of direct foreign investment towards China should be taken into account. Wei (1995) explore the determinants of inward FDI in China and India and the causes for their huge difference. It was found that China's much higher FDI from OECD countries was mainly due to its larger domestic market and higher international trade ties with OECD countries. India, however, had advantage in its cheaper labor cost, lower country risk, geographic closeness to OECD countries, and cultural similarity.

From the researches before, we can see that many researches are focus on comparing economic development between India and China, but there are less researches on Brazil and Russia. Moreover, the determinants of their industrial patterns of inward foreign direct investment in the BRICs should be pay more attention.

\section{Comparison}

\subsection{Overall Trends}

Although the BRICs have attracted more and more FDI in recent years, their growth rates and paths are not the same. From figure 1, we can see that China is growing the fastest among the BRICs from 1994-2007, and reaches about 140 billion US dollars in 2007. Brazil has a rapid decline from 2001 to 2003 and then increases slowly. Russia and India both develop smoothly and increase a lot from 2005. According to the UNCTAD, Brazil, China and Russian Federation are belong to high FDI potential and low FDI performance. However, India is both low FDI potential and low FDI performance (Matrix of inward FDI performance and potential, 2006).

\section{$<$ Insert Figure 1 here $>$}

\subsection{Industrial Pattern}

From figure 2 we can see that FDI stock in Brazil in the primary sector is at a lower level and declined largely in 2002, while FDI in the secondary sector increased slightly. FDI in the service sector declined from $\$ 1.6$ billion in 2001 to $\$ 1.0$ billion in 2002.

$$
\begin{aligned}
& <\text { Insert Figure } 2 \text { here> } \\
& <\text { Insert Figure } 3 \text { here> }
\end{aligned}
$$

Figure 3 shows us that the FDI inflows in Russia fluctuated substantially. The tertiary sector registered substantial increases in FDI flows during 1998-2000. By 2001, the tertiary sector received about $50 \%$ of total FDI inflows. The secondary sector lost its share compared to 1998, but still receives about $30 \%$ of total FDI. Finally, the ups and downs of the primary sector reflect the FDI flows in the petroleum sector which fell by $70 \%$ in 2000 to US $\$ 400$ million.

In India, the inward FDI stocks for specific sectors and industries reveal a tremendous shift from FDI in the secondary and the manufacturing sectors to FDI in the tertiary and service sectors since 1995 (Figure 4, Chakraborty and Nunnenkamp, Economic Reforms, FDI, and Economic Growth in India: A Sector Level Analysis, World Development Vol. 36, No. 7, pp. 1192-1212, 2008). From the study of Chakraborty and Nunnenkamp, in the manufacturing sector, all previous priority areas accounted for steeply decreasing shares in overall FDI stocks. The data of FDI in services is increasing rapidly. This is mainly because the definition of services sector is largely confined to the unspecified category of "other services", and this category is heavily concentrated in information and communication services.

$$
\begin{aligned}
& <\text { Insert Figure } 4 \text { here> } \\
& <\text { Insert Figure } 5 \text { here> } \\
& <\text { Insert Table } 1 \text { here }>
\end{aligned}
$$

In China, the situation is also different. The secondary sector is the main receiving station of inward FDI and the volume of the FDI is increasing rapidly and consistently. The FDI flows to secondary sector in China reaches about 2000 billion dollar in 2007, which is the highest in the BRICs. However, the primary and tertiary sectors are at a lower level of FDI inflow, and only have a slightly increase in the past decade. 
As is mentioned above, the overall trend of the inward FDI in the BRICs is increasing. Nevertheless, the industrial patterns of inward FDI are different from each other. In Brazil, Russia and India, the tertiary sector receives the most inward FDI on average over the past decade, while the primary sector receives the least and the secondary sector is in the middle. But China has a special industrial patterns of inward FDI, that is, the secondary sector dominant the majority of the inward FDI and the primary and tertiary sectors receive only a bit. We also can see this from table 1 . The table gives the three most important industries in terms of FDI stock in the BRICs. In Brazil, business activities accounts for $31 \%$ of its total inward FDI in 1998, finance accounts for $12 \%$, and electricity, gas and water accounts for $8 \%$. While in Russia, the transport accounts for $21 \%$, food accounts for $20 \%$, and trade accounts for $12 \%$ in the same year. From 1987 to 2002, the annual average of other services accounts for $51 \%$ of the total inward FDI in India, chemicals accounts for $10 \%$, and machinery accounts for $10 \%$. In China, the manufacturing accounts for $58 \%$ of its total inward FDI on average from 1987 to 2007, and all the three most important industries in China belong to the secondary sector.

\section{Determinants}

As we all know, the industrial patterns of inward foreign direct investment in the BRICs vary from each other, so we should find out the determinants. In my opinion, there are three main factors that determinant the industrial patterns of inward foreign direct investment in the BRICs.

\subsection{Develop Course}

Brazil's position in international market is better than India and China before the democratic independence. It can control over its fate, and has a comparative advantage in all aspects. Brazil becomes independent at an early time. So it has been long to form an elite political group which represents the northern and southern manufacturers, and by the Great Depression and World War I, Brazilian government began to confiscate the assets of the United Kingdom and the United States and gradually implemented import substitution-oriented economic policies to promote economic expansion. Since the 30th to early 50th, the Brazilian economy continues to have around $6 \%$ growth. At that time, Brazil has obtained a more favorable position in the international division than China and India. World War II brought great order to Brazil, as a result, the Brazilian economy boomed.

At the beginning of Indian foundation, India has not encountered large-scale war for 200 years. It has good industrial system, prevailing legal system, accounting system and statistical system. Before the arrival of the first oil crisis, India is not only near the world's two major crude oil production, but has good internal and external factors than China. As early as 1928, the League of Nations had regard India as the world's 8 major industrial nations.

China in the three countries, neither is not the first colonized, nor the deepest, half of the 20th century, China suffered the deepest domestic crisis and the biggest blow of aggression. Finally in 1949 the Chinese people stood up to go its own way. From 1979, China used gradualist economic reform, with FDI regulation and moderately low country risk. Then, China opened more and had a high level of inward FDI. In the short run, China will have high levels of investment, exporting and job-creation but low commitment and innovation in the long run (Buck, Filatotchev, Nolan and Wright, 2000).

Russia used shock therapy, which is totally different from China, with insider privatization and extremely high country risk. So it has low levels of inward FDI, investment and exporting, but job preservation in the short run. However, incumbents may change their attitudes towards foreign investors and there will be an increasing inward FDI (Buck, Filatotchev, Nolan and Wright, 2000).

\subsection{Resources}

Compared with China, the most prominent advantage of Brazil is that it has a very rich natural resources. Brazil has more than 300 million hectares plowland that is 3 times of China, and the population of Brazil is only 1/9 of China's. The unused land in Brazil is more than 100 million hectares which is the same as China's total plowlandland. Brazil has the world's largest tropical rain forest, and the area is more than 500 million square kilometers. Brazil is extremely rich in mineral resources, and reserves iron ore of about 48 billion tons. Brazil has a good prospect on agricultural good export market, and the Brazilian beef export is showing rapid growth trend. Another characteristic of Brazil is that the energy technology development has started early in the 70th last century.

Russia's natural resources are also very rich. It has more than $90 \%$ of forest area, $70 \%$ of the coal, $80 \%$ of natural gas, and the majority of iron ore of the former Soviet Union. Russia is a region riched in natural resources around the world. There are a large number of various metal minerals such as iron, copper, nickel, zinc, tin, gold, silver and so on. The natural conditions of the Russian Federation have a significant impact on its economic development. Broad forest belt and abundant land resources of Russia help the development of agriculture and agricultural products. The diversity of natural conditions offers a wide range of possibilities for Russia's economic development.

Compared with China, India has advantages in some aspects. First, the software industry, India's software industry is 
one of the best in the world. India currently has a large number of professionals. According to McKinsey's report, by 2008, India's IT services and logistics will have four million employees, and the annual exports will reach 57 billion U.S. dollars, accounted for 7\% of total India's GDP. In contrast, China's software industry develops late, and has a large gap with India's. Second, financial institutions, India has a relatively sound financial system, with lower proportion of non-performing loans and non-performing loan rate of commercial banks was only $10.8 \%$. India's more mature stock markets, become an important place for raising funds for Indian companies. However, the social infrastructure in India is several decades behind China, which is the main bottleneck constraining economic development in India.

It is known to all that China is riched in labour force with low cost. In addition that, China also have rich nature resources and big domestic market, which makes it is valuable to invest in China.

\subsection{Business Environment}

For starting a business, Russia is ranked 33rd out of 175 economies in 2006, which indicates that barriers to start a business are not high (Aidis and Adachi, 2007). While Brazil has the longest duration and India has the highest cost. For dealing with licenses, Russia has the longest time and India still has the highest cost. The difficulty of hiring workers is the biggest in Brazil, while the difficulty of firing workers is the biggest in India. But the firing costs are not the highest in India but in China. Moreover, it is more difficult to get credit in Russia and India than Brazil and China. The investor protection in the BRICs is near the OECD average level. But the total tax rates in the BRICs are higher than the OECD average level. The cost to import in China is quite low compared with the BRICs but the cost of closing a business in China is the highest (doing business data, 2006).

From the different develop courses, resources and business environment, we can see that the BRICs have different advantages and disadvantages that make them have different industrial patterns of inward foreign direct investment now.

\section{Conclusions}

This paper compares the overall trends and industrial patterns of inward foreign direct investment in the BRICs and explains their determinants. The overall trend of the inward FDI in the BRICs is increasing. Nevertheless, the industrial patterns of inward FDI are different from each other. In Brazil, Russia and India, the tertiary sector receives the most inward FDI on average over the past decade, while the primary sector receives the least and the secondary sector is in the middle. But China has a special industrial patterns of inward FDI, that is, the secondary sector dominant the majority of the inward FDI and the primary and tertiary sectors receive only a bit. In addition, there are three main factors that determinant the industrial patterns of inward foreign direct investment in the BRICs: develop courses, resources and the business environment.

This paper fills the gap of study on the industrial patterns of inward foreign direct investment in the BRICs, which can give help to the further study. However, the study of the determinants of the industrial patterns of inward foreign direct investment in the BRICs still belongs to theoretical analysis. I did not find the data to do the empirical analysis, so the results need to be proved further more.

\section{References}

Chandana Chakraborty., \& Peter Nunnenkamp. (2008). Economic Reforms, FDI, and Economic Growth in India: A Sector Level Analysis. World Development, Vol. 36, No. 7, pp. 1192-1212.

Chu-Ping, LO., \& Bih Jane, LIU, (2009). Why India is mainly engaged in offshore service activities, while China is disproportionately engaged in manufacturing? China Economic Review, 20: 236-245.

Hui Fang Cheng, Margarida Gutierrez, Arvind Mahajan, Yochanan Shachmurove., \& Manuchehr Shahrokhi. (2007). A future global economy to be built by BRICs. Global Finance Journal, 18: 143-156.

Jesus Felipe, Editha Laviñ A., \& Emma Xiaoqin Fan. (2008). The Diverging Patterns of Profitability, Investment and Growth of China and India During 1980-2003. World Development, Vol. 36, No. 5, pp. 741-774.

Jose' Miguel GINER., \& Graciela GINER. (2004). An interpretative model of foreign direct investment in China: An economic policy approach. China Economic Review, 15: 268- 280.

Nathalie Fabry., \& Sylvain Zeghni. (2002). Foreign direct investment in Russia: how the investment climate matters. Communist and Post-Communist Studies, 35: 289-303.

Ruta Aidis., \& Yuko Adachi. (2007). Russia: Firm entry and survival barriers. Economic Systems. 31 :391-411.

Scott Mcdonaldm, Sherman Robinson, Karen Thierfelder, (2008). Asian growth and trade poles: India, China, and East and Southeast Asia. World Development, Vol. 36, No. 2, pp. 210-234, 2008.

Shang-Jin Wei, (1995). Attracting foreign direct investment: Has China reached its potential? China Economic Review, Volume 6, Number 2, pages 187-199. 
Trevor Buck, Igor Filatotchev, Peter Nolan., \& Mike Wright. (2000). Different Paths to Economic Reform in Russia and China: Causes and Consequences. Journal of World Business, 35(4).

Table 1. The three most important industries in terms of FDI stock in the BRICs

\begin{tabular}{|c|c|c|}
\hline Year & Brazil & Russian Federation \\
\hline 1990 & $\begin{array}{c}\text { Other services }(17 \%) \text {, chemicals }(14 \%) \text {, motor } \\
\text { vehicles }(10 \%)\end{array}$ & \\
\hline 1995 & $\begin{array}{c}\text { Business activities }(31 \%) \text {, chemicals }(11 \%), \\
\text { metal and metal products }(7 \%)\end{array}$ & \\
\hline 1998 & $\begin{array}{c}\text { Business activities }(31 \%) \text {, finance }(12 \%) \text {, } \\
\text { electricity, gas and water }(8 \%)\end{array}$ & Transport $(21 \%)$, food $(20 \%)$, trade $(12 \%)$ \\
\hline 2002 & & Transport $(25 \%)$, mining $(16 \%)$, food $(15 \%)$ \\
\hline & India & China \\
\hline $\begin{array}{l}1987-2002 \\
\text { (average) }\end{array}$ & $\begin{array}{l}\text { Other services }(51 \%) \text {, chemicals }(10 \%), \\
\text { machinery }(10 \%)\end{array}$ & \\
\hline $\begin{array}{r}1987-2007 \\
\text { (average) }\end{array}$ & & $\begin{array}{c}\text { Manufacturing }(58 \%) \text {, real estate }(15 \%), \\
\text { electricity, gas and water }(7 \%)\end{array}$ \\
\hline
\end{tabular}

Source: World Investment Directory online and China Economics Information Online Database

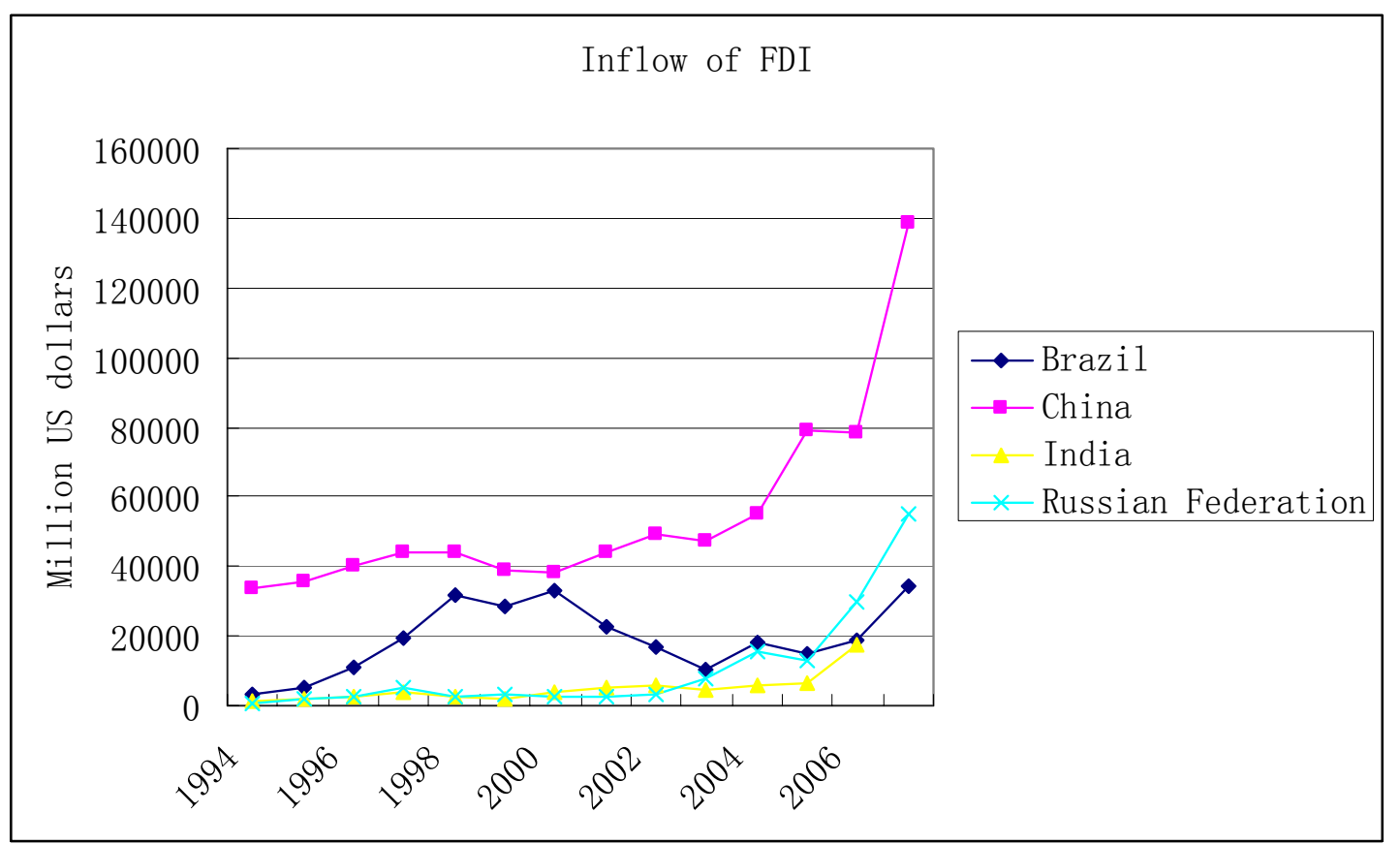

Figure 1. Inflow of FDI in the BRICs (1994-2007)

Source: OECD Factbook 2009: Economic, Environmental and Social Statistics 


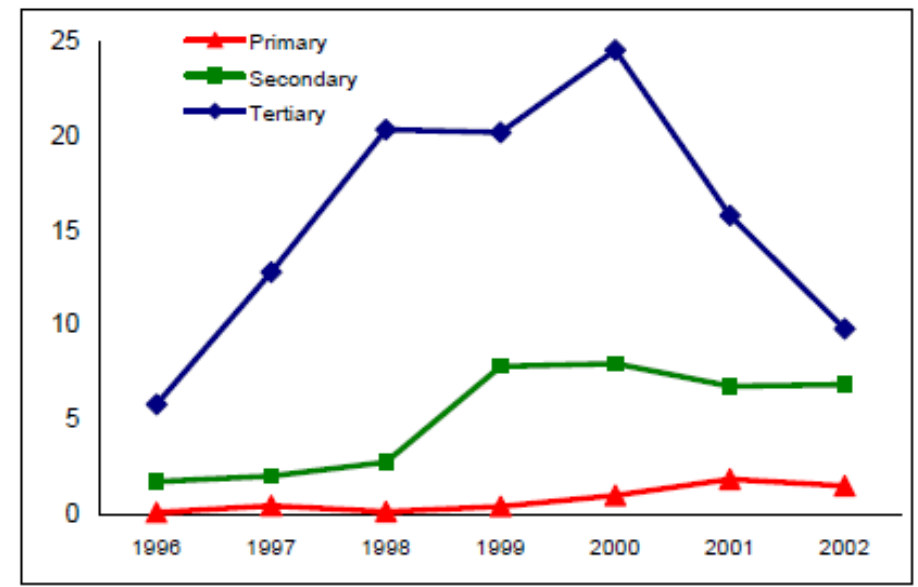

Figure 2. FDI inflows by industry, Brazil, 1996-2002 (Billions of dollars)

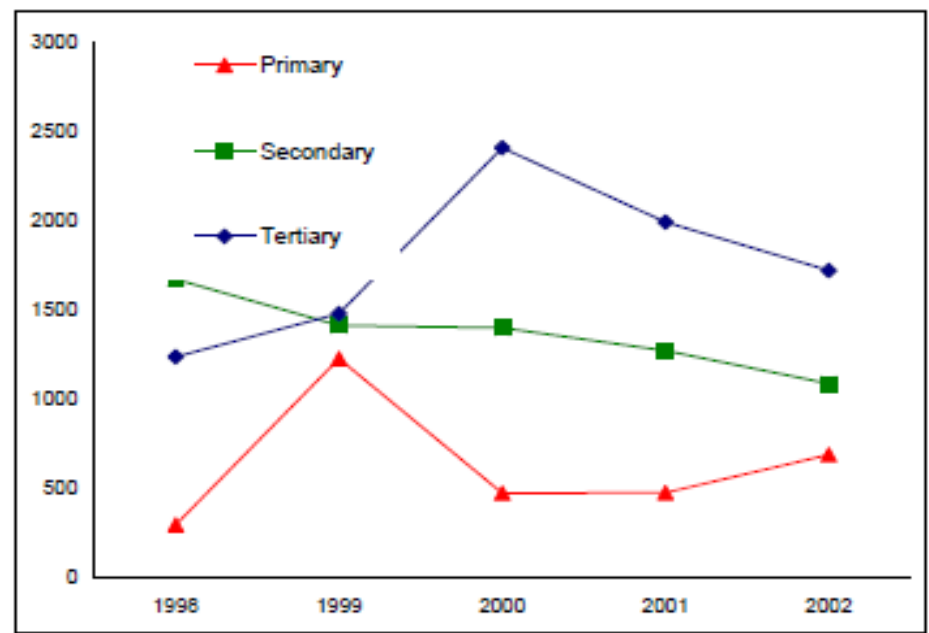

Figure 3. FDI inflows by industry, Russian Federation, 1998-2002(Billions of dollars)

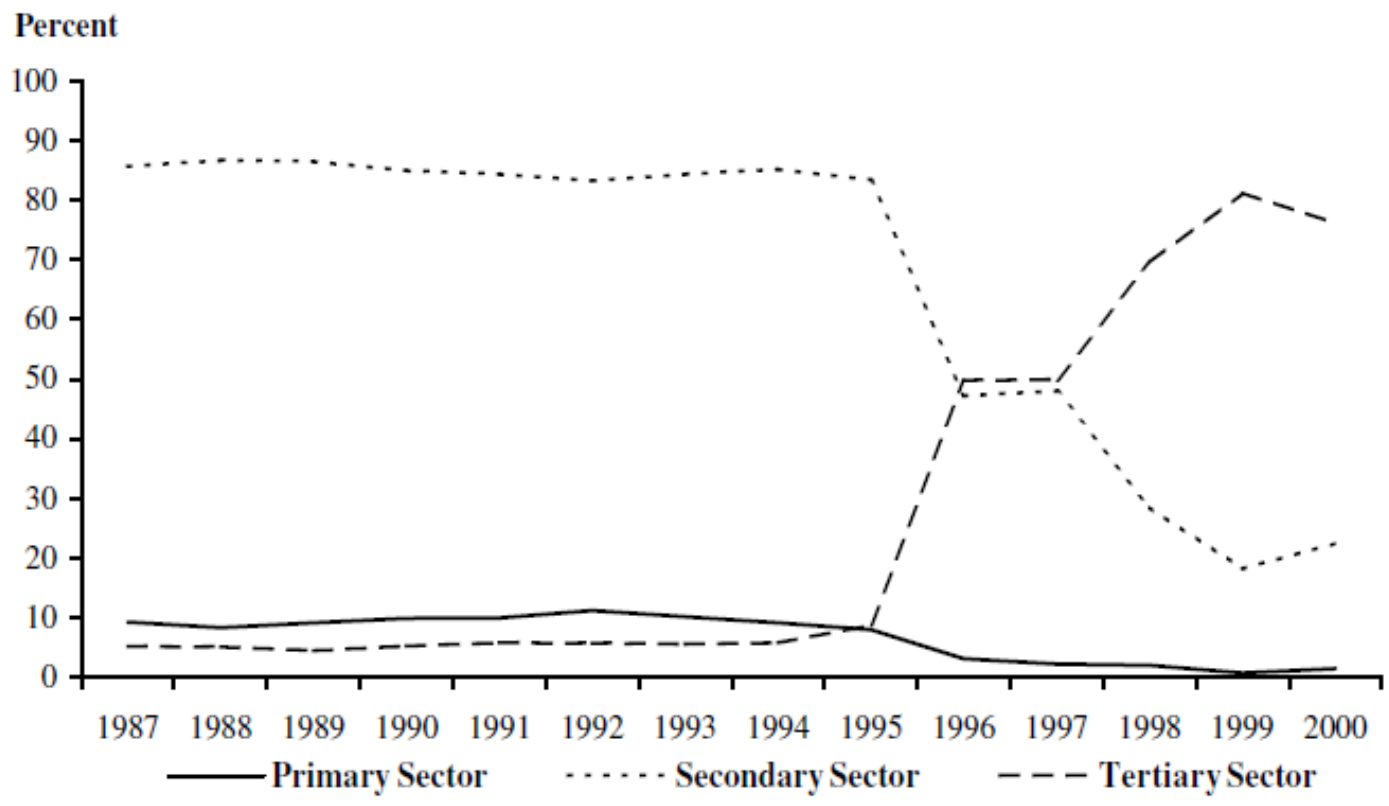

Figure 4. Sector-wise composition of FDI Stocks, India, 1987-2000

Source: UNCTAD (2000) and Central Statistical Organisation (various issues). 


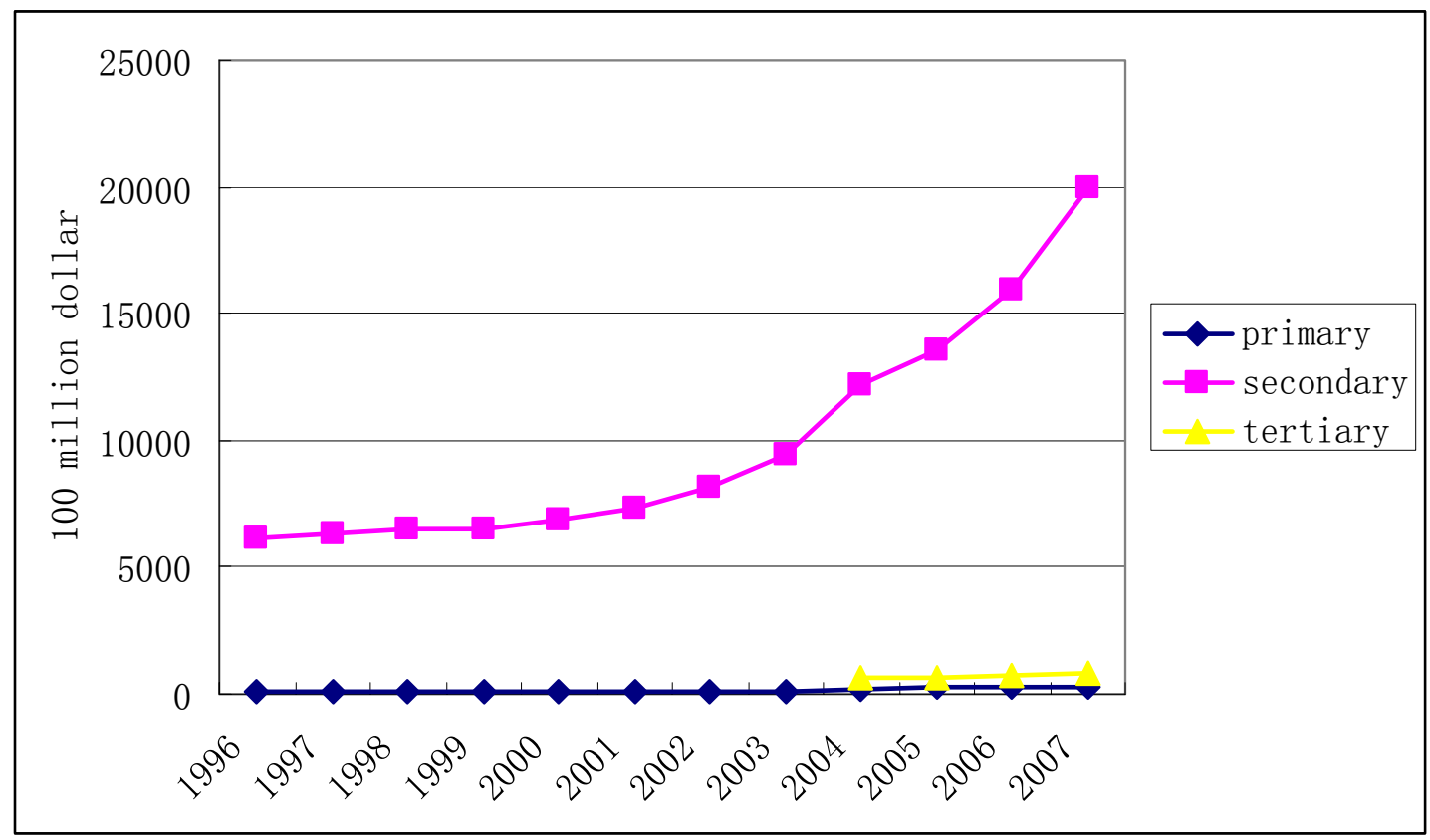

Figure 5. FDI inflows by industry, China, 1996-2007

Source: China Economics Information Online Database 